Jurnal IImiah AL-Jauhari (JIAJ)

Volume 2 No 2, Desember 2017

ISSN: $2541-3430$

E-ISSN: 2541-3449

Halaman 243-256

\title{
Pendidikan tentang Manusia dalam Perspektif Al-Qur’an
}

\author{
Oleh: Sulaiman Ibrahim \\ (IAIN Sultan Amai Gorontalo) \\ sulaiman@iaingorontalo.ac.id
}

\begin{abstract}
ABSTRAK
Manusia dalam kaitannya dengan pendidikan, adalah merupakan makhluk ciptaan Tuhan yang memliki potensi untuk dapat berkembang ke arah yang positif sekaligus memliki potensi untuk berkembang ke arah yang negatif. Demikian pula keberadaan manusia di dunia yang dilengkapi dengan dua unsur, yaitu unsur jasad dan ruh, realitas yang mendasari dan prinsip yang menyatukan apa yang kemudian dikenal sebagai manusia bukanlah perubahan jasadnya melainkan keruhaniannya. Hal itu dapat dicapai jika potensi yang ada dalam dirinya diarahkan kepada yang positif melalui pendidikan.
\end{abstract}

Kata kunci: Pendidikan, Manusia, al-Qur'an

\section{Pendahuluan}

Dalam suasana perkembangan ilmu pengetahuan dan teknologi dewasa ini, masalah hakekat manusia serta yang menyangkut dengan seluruh aspek kehidupannya semakin santer dibahas. Persoalan ini memang sangat penting, karena ia merupakan tolok ukur dalam melihat fungsi manusia secara keseluruhan dalam kehidupannya. ${ }^{1}$

Di satu sisi, kemajuan ilmu pengetahuan dan teknologi tersebut belum tentu dapat menjamin kebahagiaan hidup manusia, bahkan secara realita, justeru dapat menyebabkan timbulnya berbagai problema dalam kehidupan. Hal ini membuktikan bahwa kemajuan ilmu pengetahuan dan teknologi tersebut hanya dapat menciptakan pribadi-pribadi manusia yang bersifat satu dimensi, sehingga walaupun manusia itu mampu berbuat segala sesuatu, namun ia masih sering

\footnotetext{
${ }^{1}$ M. Quraish Shihab, Membumikan Alquran, Fungsi dan Peran Wahyu dalam Kehidupan bermasyarakat, Cet. XX, (Bandung: Mizan, 1999), h. 224
} 
bertindak secara tidak adil. Hal ini membuktikan bahwa manusia memiliki orientasi untuk menjadi pribadi yang bergerak di antara dua titik ekstrem, yakni Allah - Setan. ${ }^{2}$ Proses selanjutnya adalah terserah kepada manusianya itu sendiri, apakah nilai-nilai kemajuan ilmu pengetahuan dan teknologi tersebut akan ia tundukkan di bawah nilai-nilai spiritual religius atau tidak. Artinya, kemajuan ilmu pengetahuan dan teknologi itu harus dijadikan sebagai sarana untuk mengembangkan potensi agar dapat meniru sifat-sifat Allah, serta dijadikan sebagai alat kontrol dalam menekan potensi agar tidak meniru sifat-sifat setan.

Di samping itu, kemajuan ilmu pengetahuan dan teknologi juga pada kenyataannya belum mampu menjawab secara tuntas pertanyaan tentang hakekat manusia itu sendiri. ${ }^{3}$

Pembahasan tentang hakekat manusia ini sangat penting, terutama jika dikaitkan dengan masalah pendidikan. Artinya, perlu untuk diketahui bahwa unsur-unsur apa saja yang terdapat dalam diri manusia, apakah manusia itu benarbenar memiliki potensi untuk dididik dan mendidik. Dengan adanya pengetahuan tentang hakekat manusia, barulah dapat digariskan ke mana pendidikan itu akan diarahkan.

Berdasarkan uraian diatas, makalah ini mencoba melihat bagimana pandangan Al-Quran tentang hakekat manusia yang ditinjau dari sudut pandang pendidikan.

\section{Istilah Manusia dalam Al-Quran}

Terdapat tiga macam ungkapan tentang istilah manusia yang digunakan AlQuran, yaitu:

A. Menggunakan ungkapan إنْنَان. Para ulama berbeda pendapat tentang kata tersebut, ulama yang memegang pendapat ini mengatakan bahwa kata إنْسَان berakar dari kata يَنَنَسَى - نَبنَّ yang berarti "lupa". Argumen yang mereka kemukakan adalah bentuk tashgir dari kata tersebut yakni أَنَّبسيًِا pendapat ini diperkuat oleh perkataan Ibnu Abbas bahwa manusia disebut dengan ins $\pm n$ karena melupakan janjinya kepada Tuhan.

إنْيًًا bendapat kedua mengatakan bahwa, kata إنْسَـان beral dari kata yang berakar kata dari إِنّْ pendapat ini menolak pendapat di atas dengan alasan bahwa huruf ya yang terdapat dalam kata unaisiyan adalah huruf tambahan seperti halnya huruf ya yang terdapat pada kata رَزَوْيجَن yang berarti laki-laki. ${ }^{4}$

Pendapat ketiga mengatakan bahwa, kata إنْنَانَ berasal dari kata نَاسن ban يَنُوْنُ yang berakar kata dengan huruf nun, waw dan sin yang memiliki makna dasar "goncangan atau bergoncang". 5

\footnotetext{
${ }^{2}$ Manusia memiliki potensi untuk mencontoh sifat-sifat Tuhan serta memiliki potensi untuk mencontoh sifat-sifat setan. Lihat Mastuhu, M.Ed., Memberdayakan Sistim Pendidikan Islam, Cet. II, (Jakarta: Logos Wacana Ilmu, 1999), h. 25.

${ }^{3}$ M. Quraish Shihab, Wawasan Alquran, Tafsir Maudhu'i Atas Pelbagai Persoalan Ummat, Cet. VII, (Bandung: Mzan, 1998), h. 277 - 278.

${ }^{4}$ Ibnu Mukarram Ibnu Manzur, Lisan al- 'Arabi, Jilid VI, (Mesir: Dar al-Shadr, 1969), h. 11.

${ }^{5}$ Ahmad Ibnu Muhammad al-Fayuny, Al-Mishbah al-Munir fi Gharib al-Syarh al-Kabir li al-Rafi'i, (Kairo: Dar al-Fikr, t.th.), h. 302.
} 
Di samping istilah-istilah tersebut di atas, terdapat pula kata yang hampir mirip yakni آلنَّاسُ kata ini digunaka oleh Al-Quran sebanyak 241 kali, dan kata ini terkadang berarti untuk semua jenis manusia seperti terdapat dalam

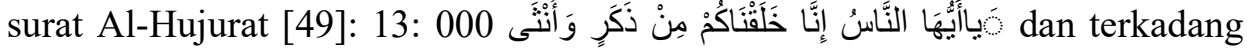
pula berarti hanya sekelompok manusia, seperti terdapat pada surat Ali Imran

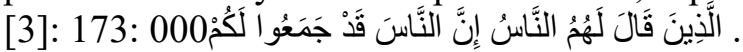

Terlepas dari perbedaan yang ada, makna-makna di atas, paling tidak memberikan gambaran sepintas tentang potensi atau sifat manusia yaitu bahwa ia memiliki sifat-sifat lupa, mempunyai kemampuan untuk bergerak yang melahirkan dinamika, serta manusia itu tidak jarang pula mengalami kegoncangan dalam jiwanya.

B. Menggunakan ungkapan بَتَـَ yang berakar kata dengan huruf $b a$, syin dan $r a$, yang bermakna pokok "nampaknya sesuatu dengan baik dan indah". Dari makna ini terbentuk kata kerja بَتَََْر dengan arti bergembira, menggembira-kan

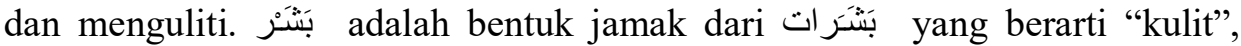
manusia disebut basyar karena kulitnya tampak jelas dan berbeda dengan kulit makhluk lainnya. Kata ini dalam Al-Quran secara khusus merujuk kepada tubuh dan lahiriah manusia. ${ }^{6}$

Jika kata basyar dalam Al-Quran diklasifikasikan maka pengguna-annya terhadap yang berkaitan dengan aspek biologis seperti makan dan minum

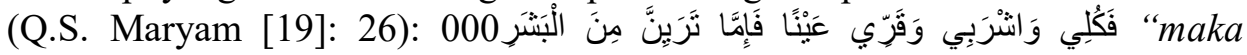
makan, minum dan bersenang hatilah kamu. Jika kamu melihat seorang manusia...". Yang berkaitan dengan aspek bahwa manusia bisa berkembang biak (Q.S. Al-Rum [30]: 20): "Dan di antara tanda-tanda kekuasaan-Nya Dia menciptakan kamu dari tanah, kemudian tiba-tiba kamu menjadi manusia yang berkembang biak". Berkaitan dengan manusia memiliki sosok fisik yang sempurna dibanding

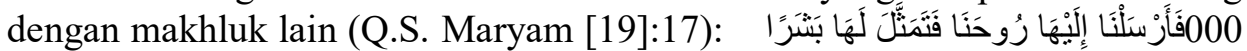
سَوِيَّا "lalu Kami mengutus roh Kami kepadanya, maka ia menjelma di hadapannya dalam bentuk manusia yang sempurna”. Dan penjelasan tentang

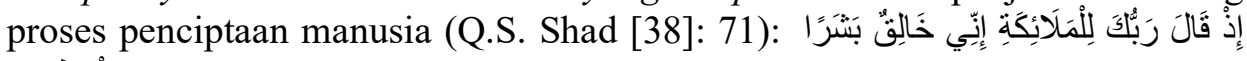
Ingatlah ketika Tuhanmu berfirman kepada Malaikat; Sesungguhnya Aku akan menciptakan manusia dari tanah". Selain ayat tersebut di atas, masih terdapat banyak ayat yang menjelaskan tentang penggunaan kata basyar yang berkaitan dengan pengklasifikasian tersebut.

C. Menggunakan ungkapan زريات آدم dan بنى آد م

Kedua istilah ini berbeda dengan dua istilah sebelumnya, istilah $b^{3}{ }^{3}$ Adam dan zurriy $\pm t$ Adam merujuk kepada manusia, karena adanya kaitan dengan kata Adam yang merupakan manusia pertama yang diciptakan Allah dan mendapat penghormatan yang lebih dibanding dengan makhluk-makhluk ciptaan Allah lainnya.

${ }^{6}$ Abu al-Qasim bin Muhammad al-Ashfahani al-Raghib, Mufradat fi Gharib Al-Quran, (Mesir: Mushthafa Bab al-Halabi, 1961), h. 28. 
Kedua istilah di atas diartikan dengan "keturunan" tetapi mempunyai konotasi yang berbeda. Kata $b^{3} n^{3}$ berarti sesuatu yang lahir dari yang lain, sedangkan kata zurriy $\pm t$ mempunyai arti "kehalusan" dan "tersebar". Dikaitkannya kedua istilah tersebut dengan kata Adam, memberi kesan kesejarahan dalam konsep manusia yakni bahwa seluruh makhluk yang namanya manusia mempunyai satu asal yang sama pula. ${ }^{7}$

Dari pendekatan bahasa tersebut, dapat ditarik kesimpulan bahwa kata $b a^{3}$ Adam memberikan dasar kesejarahan bagi seluruh ummat manusia, sedangkan kata zurriy $\pm t$ Adam mengandung konsep keragaman manusia yang tersebar dalam berbagai warna, suku dan bangsa.

\section{Beberapa Ciri dan Unsur dalam Diri Manusia}

Manusia dapat menjalankan peranan idealnya jika ia memiliki pengetahuan cukup yang berkaitan dengan peranan itu serta kemauan dan kemampuan untuk menjalankannya. Oleh karena itu, manusia harus mengembangkan berbagai potensi yang ada dalam dirinya, dan untuk itu maka manusia perlu mengetahui fitrahnya.

Berkaitan dengan hal tersebut di atas, perlu dilihat beberapa unsur yang terdapat dalam diri manusia yaitu; nafs, qalb, ruh dan akal.

1. Nafs ( النفس )

Kata nafs dalam Al-Quran mempunyai aneka makna, terkadang menunjuk kepada totalitas manusia, terkadang menunjuk kepada apa yang terdapat dalam diri manusia yang menghasilkan tingkah laku. Namun secara umum dapat dikatakan bahwa nafs dalam konteks pembicaraan tentang manusia, menunjuk kepada sisi dalam manusia yang berpotensi baik dan buruk. ${ }^{8}$

Kata nafs juga menunjukkan makna bahwa manusia merupakan makhluk yang asalnya satu, berkembang biak, bekerja dan merasa. Juga kadang-kadang menunjukkan watak dan inti manusia atau untuk menunjukkan sesuatu yang tertentu. ${ }^{9}$

Al-Quran menegaskan bahwa nafs memiliki potensi positif dan negatif, namun potensi positifnya lebih besar dibanding potensi negatifnya, hanya saja daya tarik keburukan lebih kuat dari pada daya tarik kebaikan. Oleh karena itu, manusia dituntut untuk senantiasa memelihara potensi nafs agar ia selalu dalam keadaan suci:

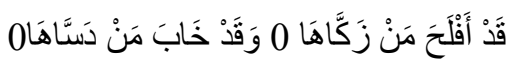

Sesungguhnya beruntunglah bagi orang-orang yang mensucikannya. Dan merugilah bagi orang-orang yang mengotorinya. (Q.S. Al-Syams [91]: 9-10)

Dalam pada itu, nafs atau yang juga disebut jiwa mempunyai dua daya, yakni daya berfikir yang disebut akal yang berpusat dikepala, dan daya rasa yang berpusat di kalbu atau di dada. Dengan demikian, kata nafs dalam Al-Quran menunjukkan kepada diri (self) sebagai keseluruhan yang lebih menyatakan

\footnotetext{
${ }^{7}$ Ibid., h. 62 dan 177.

${ }^{8}$ M. Quraish Shihab, Wawasan Al-Quran, Op., Cit., h. 285 - 286.

${ }^{9}$ Hasan Langgulung, Azas-Azas Pendidikan Islam, Edisi Revisi, Cet. I, (Jakarta: PT. A1Husna Dzikra, 2000), h. 302.
} 
motivasi dan aktivitas hidup dari pada makna yang sadar. Atau, ia merupakan kata umum yang meliputi manusia sebagai keseluruhan, bukan hanya aspek pemikiran dan pemahaman saja.

2. Qalb (قلب)

Kata qalb atau hati tidak sebanyak jumlah pamakaiannya dengan kata nafs dalam Al-Quran, tampaknya kebanyakan artinya berkisar pada arti perasaan atau emosi dan intelektual pada manusia. Oleh sebab itu ia merupakan dasar bagi fitrah yang sehat, berbagai perasaan, baik mengenai perasaan cinta atau benci, dan tempat petunjuk, iman, kemauan, kontrol dan pemahaman. ${ }^{10}$

Kata qalb terambil dari akar kata yang bermakna "membalik" karena seringkali ia berbolak balik, terkadang senang terkadang susah, terkadang menerima terkadang menolak. Qalb memiliki potensi untuk tidak konsisten, AlQuran-pun menggambarkan hal yang demikian seperti berikut:

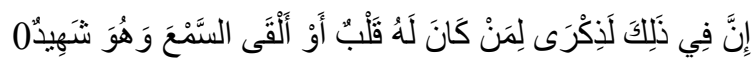

Sesungguhnya yang demikian itu benar-benar terdapat peringatan bagi orang yang memiliki qalbu, atau yang mencurahkan pendengaran lagi menjadi saksi. (Q.S. Qaaf [50]:37)

Dari ayat tersebut di atas, terlihat bahwa qalb adalah sebagai wadah pengajaran, kasih sayang, takut dan keimanan, di samping itu ia merupakan wadah bagi fitrah yang sehat. Sebagaimana halnya dengan nafs yang merupakan "sisi dalam" manusia, maka qalb juga demikian, hanya saja qalb berada dalam satu kotak tersendiri yang bertempat dalam kotak besar nafs.

Di samping itu, kata qalb dalam Al-Quran memiliki arti yang lebih khusus dari pada arti nafs. Ia tidak menunjukkan motivasi naluriah, tetapi khusus mengenai aspek yang sadar saja.

\section{Ruh ( روح)}

Kata $r-h$ yang terdapat dalam Al-Quran penggunaannya macam-macam, kata ini menunjukkan pemberian hidup oleh Allah kepada manusia. Kata $r-h$ selalu dikaitkan sebagai milik Allah, oleh sebab itu berbicara tentang $r$ - $h$ AlQuran mengingatkan kita seperti dalam firman-Nya:

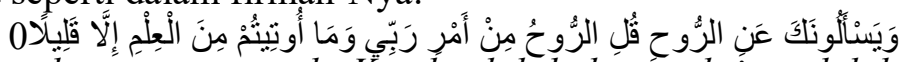

Dan mereka bertanya kepadamu tentang ruh. Katakanlah bahwa ruh itu adalah urusan Tuhanku, kamu tidak diberi ilmu kecuali sedikit. (Q.S. Al-Isra' [17]: 85)

Ayat tersebut di atas, nampaknya memberi isyarat bahwa bagaimanapun tingginya ilmu pengetahuan manusia, namun ada batas-batas yang ia tidak mampu untuk mengetahui. Disamping itu, yang menambah sulitnya persoalan adalah kata ruh terulang dalam Al-Quran dalam berbagai konteks dan makna dan tidak semua penggunaannya berkaitan dengan manusia. ${ }^{11}$ Penggunaannya yang berkaitan dengan manusiapun memiliki makna yang berbeda pula.

4. 'Aql (عقل )

Kata 'aql tidak pernah muncul dalam Al-Quran sebagai kata benda abstrak atau mashdar sama sekali. Tetapi sebagai kata-kata kerja dengan berbagai bentuknya berkali-kali Al-Quran menggunakannya. Dan secara keseluruhan

\footnotetext{
${ }^{10}$ Ibid., h. 303.

${ }^{11}$ M. Quraish Shihab, Wawasan Al-Quran, Op. Cit., h. 292. Bandingkan dengan Hasan Langgulung, Op. Cit., h. 304.
} 
penggunaannya menunjukkan kepada berbagai macam aspek pemikiran pada manusia, seperti beberapa contoh ayat berikut:

a. Menunjukkan kepada daya untuk memahami dan menggambarkan sesuatu:

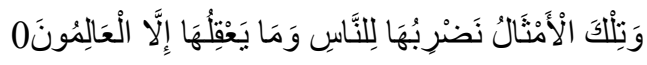

Demikian itulah perumpamaan-perumpamaan yang Kami berikan kepada manusia, akan tetapi tidak ada yang memahaminya kecuali orang-orang alim (berpengetahuan). (Q.S. Al-Ankabut [29]: 43)

Daya manusia dalam hal ini berbeda-beda, ini diisyaratkan oleh AlQuran antara lain dalam ayat-ayat yang berbicara tentang kejadian langit dan bumi, silih bergantinya siang dan malam. Disamping itu, keanekaragam-an akal dalam konteks menarik makna dan menyimpulkannya terlihat juga dari penggunaan istilah-istilah seperti; نظر (naßara), تفكر (tafakkur), تد بر (tadabbur) dan lain-lain yang kesemuanya mengandung makna mengantar kepada pengertian dan kemampuan pemahaman.

b. Menunjukkan kepada dorongan moral, seperti dalam ayat:

000

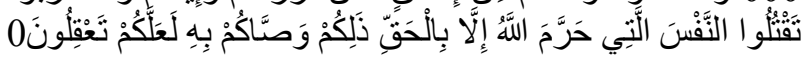

...dan janganlah kamu mendekati perbuatan-perbuatan keji, baik yang nampak atau yang tersembunyi, dan janganlah kamu membunuh jiwa yang diharamkan oleh Allah tanpa sebab yang benar. Demikian itu diwasiatkan Tuhan kepadamu, semoga kamu memiliki dorongan moral untuk menjauhinya. (Q.S. Al-An'am [6]: 151)

c. Menunjukkan daya untuk mengambil pelajaran dan kesimpulan serta hukmah.

Daya ini menggabungkan kedua daya yang tersebut di atas, sehingga ia mengandung daya memahami, daya menganalisis, daya menyimpulkan serta dorongan moral yang disertai dengan kematangan berfikir:

$$
000
$$

...seandainya kami mendengar dan berakal (berfikir) maka pasti kami tidak termasuk penghuni neraka. (Q.S. Al-Mulk [67]: 10)

Demikianlah sekilas beberapa unsur dan pengertian-pengertian yang ada dalam diri manusia, yang boleh jadi dapat menggambarkan tentang manusia itu sendiri, terlebih-lebih dalam kaitannya dengan pendidikan. Karena pada dasarnya, pendidikan tak lain adalah berorientasi terhadap perubahan pola tingkah laku manusia sebagai oyek sekaligus subyek pendidikan.

\section{Potensi-Potensi Manusia}

Al-Quran banyak berbicara tentang sifat-sifat dan potensi yang terdapat pada manusia, dalam hal ini ditemukan beberapa ayat yang memuji serta menyatakan kemuliaan manusia dibanding dengan makhluk-makhluk ciptaan Allah lainnya, seperti pernyataan tentang ciptaan manusia dalam bentuk dan keadaan yang sebaik-baiknya:

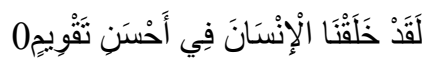

Sesungguhnya Kami telah menciptakan manusia dalam bentuk yang sebaikbaiknya. (Q.S. At-Tin [95]: 4). 
Namun di samping itu, tidak jarang pula ayat yang menyatakan tentang celaan terhadap manusia sebagai makhluk yang sangat aniaya dan mengingkari nikmat Allah, bersifat keluh kesah, banyak membantah dan lain sebagainya. ${ }^{12}$

Gambaran yang diberikan oleh Al-Quran tersebut bukanlah berarti bahwa ayat-ayatnya bertentangan antara satu dengan yang lainnya. Melainkan Al-Quran menunjukkan beberapa sisi kelemahan manusia yang harus dihindarinya, di samping ia menunjukkan bahwa makhluk ini memiliki potensi-potensi yang dapat dikembangkan. Potensi-potensi manusia dijelaskan oleh Al-Quran antara lain melaui kisah Nabi Adam dan Hawa.

Berkaitan dengan potensi-potensi yang terdapat pada manusia tersebut, maka manusia yang terdiri dari jasmani dan rohan, ia juga dianugerahi potensipotensi, yakni potensi untuk mengetahui nama dan fungsi benda-benda alam, dalam arti bahwa manusia adalah merupakan makhluk yang berkemampuan untuk menyusun konsep-konsep, mencipta, mengembangkan dan mengemukakan gagasan, serta melaksanakannya. Potensi ini adalah merupakan bukti yang membungkamkan para Malaikat ketika mereka berkeberatan jika Allah menjadikan manusia, karena mereka merasa wajar untuk dijadikan sebagai khalifah di bumi. Dan oleh karena itu mereka bersedia untuk bersujud kepada Adam. $^{13}$

Di samping itu, manusia sebagai makhluk yang tersusun dari dua unsur yakni jasmani dan rohani ia juga memiliki berbagai daya yang dapat menunjang tercapainya tujuan tersebut di atas. Dari unsur jasmani atau fisik manusia memiliki daya seperti mendengar, melihat, merasa, meraba serta mencium. Dan memiliki daya gerak seperti menggerakkan tangan, kepala, kaki, mata dan lain sebagainya, serta dapat berpindah dari satu tempat ke tempat yang lainnya. ${ }^{14}$

Dalam pada itu, manusia dari unsur roh atau jiwa - atau yang biasa disebut nafs - memiliki dua daya yakni daya fikir yang disebut akal yang berpusat di kepala, dan daya rasa yang berpusat di kalbu yang berpusat di dada. ${ }^{15}$

\section{Hakekat Manusia dalam Hubung-annya dengan Pendidikan}

Islam sangat memperhatikan terhadap pembinaan individu manusia sebagai inti yang baik bagi kelompok melalui keluarga, pembinaan individu sebagai faktor pokok dalam pembentukan keluarga-keluarga yang mencerminkan jaringanjaringan dan unit-unit pokok dalam masyarakat. Dasar pembinaan ini adalah agar manusia itu menjadi pribadi yang sehat, wajar dan seimbang. ${ }^{16}$

Al-Quran memberikan penjelasan bahwa manusia adalah makhluk yang diciptakan dari tanah, kemudian setelah sampurna kejadiannya, Tuhan menghembuskan roh ciptaan-Nya:

\footnotetext{
${ }^{12}$ M. Quraish Shihab, Wawasan Al-Quran, Op. Cit., h. 282.

${ }^{13}$ Ibid., h. 284.

${ }^{14}$ Harun Nasution, Konsep Manusia Menurut Islam, Dalam Saiful Muzani, ed., Islam Rasional, Gagasan dan Pemikiran Prof Dr. Harun Nasution, Cet. VI, (Bandung: Mizan, 2000), h. 37.

${ }^{15}$ Ibid.

${ }^{16}$ Hasan Langgulung, Op. Cit., h. 329.
} 


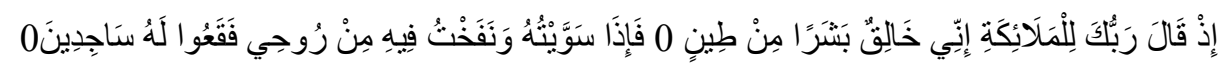

Ingatlah ketika Tuhanmu berfirman kepada malaikat: Sesungguhnya Aku akan menciptakan manusia dari tanah. Maka ketika telah Kusempurnakan kejadiannya Kutiupkan roh (ciptaan)Ku, maka hendaklah kamu tersungkur bersujud kepadaKu. (Q. S. Shad [38]: 71-72)

Di samping itu A-1Quran juga menjelaskan bahwa manusia adalah ciptaan Tuhan yang paling dimuliakan melebihi makhluk lainnya:

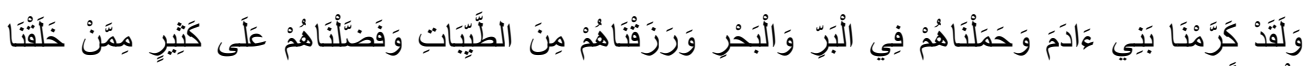
0 تَفْضِيلًا

Dan sesumgguhnya telah Kami muliakan anak-anak Adam, kami angkut mereka dilautan dan di daratan, Kami beri mereka rezki dari yang baik-baik, dan Kami lebihkan mereka dengan kelebihan yang sempurna atas kebanyakan makhluk yang telah Kami ciptakan. ( Q. S. al-Isra [17]: 70)

Kelebihan itu antara lain dengan diberikannya akal dan daya kehidupan dalam arti membentuk peradabannya. Manusia mampu menciptakan dunia kehidupannya sendiri, dan menetapkan nilai-nilai luhur yang ingin dicapai.

Dalam dunia pendidikan, manusia sering dikaitkan bahwa ia terlahir dengan membawa fitrah, yang merupakan bentuk dan sistem yang diwujudkan Allah pada setiap makhluk. Fitrah yang berkaitan dengan manusia adalah apa yang diciptakan Allah pada manusia yang berkaitan dengan jasmini, dan akal serta Rohnya. ${ }^{17}$ Merujuk kepada fitrah tersebut, dapat ditarik kesimpulan bahwa manusia sejak asal kejadiannya membawa potensi-potensi terhadap agama yang benar:

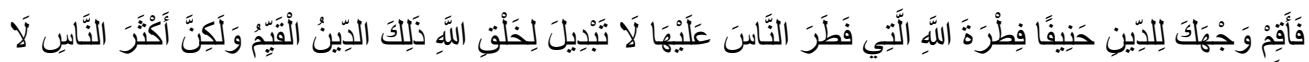

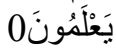

Maka hadapkanlah wajahmu dengan lurus kepada (agama) Allah, tetaplah atas fitrah Allah yang telah menciptakan manusia menurut fitrah itu, tidak ada perubahan pada fitrah Allah itu. Itulah agama yang lurus tetapi kebanyakan manusia tidak menyedarinya. (Q.S.al-Rum [30]: 30)

Dengan demikian ia juga membawa potensi-potensi untuk mendidik dan dididik, atau dengan kata lain bahwa manusia memiliki potensi untuk mengetahui nama dan fungsi benda-benda yang ada di alam raya.

Dalam sistem pendidikan umum, dikenal adanya teori "tabularasa" (John Locke) yang memandang bahwa manusia dilahirkan laksana kertas putih bersih yang kemudian sepenuhnya tergantung pada tulisan yang mengisinya, ke mana jiwa itu akan dibentuk dan dikembangkan oleh lingkungannya, ${ }^{18}$ demikian juga dikenal adanya teori "nativisme" (Arthur Schopenhauer) yang menyatakan sebaliknya.

Namun putihnya anak yang baru terlahir itu bukanlah berarti kosong samasekali, manusia menurut fitrahnya adalah makhluk terdiri dari jasmani dan rohani, dalam perkembangan pribadinya menuju martabatnya sebagai manusia, ada dua faktor yang mempengaruhi yakni faktor pembawaan dan faktor lingkungan. Dua faktor ini senantiasa saling berinteraksi sejak manusia masih dalam keadaan berupa embrio hingga akhir hidupnya. ${ }^{19}$ Maka jika demikian halnya, yang lebih

${ }^{17}$ M. Quraish Shihab, Wawasan Al-Quran, Op.Cit., h. 285.

${ }^{18}$ Mastuhu, M.Ed., Loc. Cit.

${ }^{19}$ Hery Noer Aly, MA., Ilmu Pendidikan Islam, Cet. II, (Jakarta : Logos Wacara Ilmu, 1999), h, 123. 
tepat adalah teori "Comvergensi" (William Stern) yakni perpaduan antara pembawaan dan lingkungan.

Untuk melihat keterkaitan antara manusia dengan pendidikan maka ada beberapa hal yang perlu dijelaskan sebagai berikut:

\section{A. Manusia Sebagai Makhluk Paedagogiek.}

Manusia sebagai makhluk paedagogiek, dalam arti ia memiliki potensi dan kecendurungan untuk mendidik dan dididik agar dapat berkembang, oleh sebab itu manusia tidak mungkin dapat menjalankan peranan idealnya tanpa memiliki cukup pengetahuan yang berkaitan dengan peranan itu serta kemauan dan kemampuan untuk menjalankannya.

Ajaran Al-Quran yang disampaikan oleh Nabi SAW. mengintroduksikan dirinya sebagai pemberi petunjuk kepada jalan yang lebih lurus. Petunjukpetunjuk tersebut bertujuan memberikan kesejahteraan dan kebahagiaan bagi manusia baik secara pribadi maupun kelompok. ${ }^{20}$ Petunjuk-petunjuk yang disampaikan oleh Rasulullah tersebut, mensucikan dan mengajarkan manusia.

Berkaitan dengan manusia sebagai makhluk paedagogiek, maka ia harus mengembangkan berbagai potensi yang ada dalam dirinya, dan untuk itu ia perlu mengetahuai asal kejadiannya, dari apa ia diciptakan. Dalam hal ini Al-Quran menyimpulkan dua asal kejadian manusia. Pertama, manusia dijadikan dari tanah yakni ketika Allah menciptakan Adam as., yang disebut sebagai "Bapak Manusia". Kedua, manusia dijadikan dari nuthfah yakni ketika Allah menciptakan bani Adam. ${ }^{21}$ Hal ini dapat dilihat dalam firman-Nya:

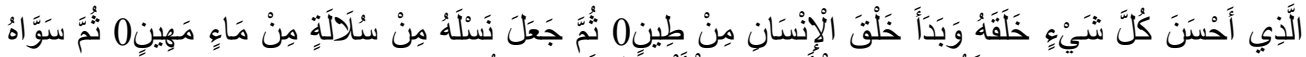

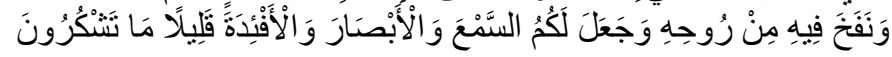

Yang membuat segala sesuatu yang Dia ciptakan sebaik-baiknya dan yang memulai penciptaan manusia dari tanah. Kemudian Dia menjadikan keturunannya dari saripati air yang hina (air mani). Kemudian Dia menyempurnakan dan meniupkan ke dalam (tubuh)nya roh (ciptaan)-Nya dan Dia menjadikan bagi kamu pendengaran, penglihatan dan hati; (tetapi) kamu sedikit sekali bersyukur. (Q.S. Al-Sajadah [32]: 7-9)

Dari ayat tersebut diatas, menunjukkan bahwa pada diri manusia terdapat dua unsur yang membentuk kejadiannya, yakni jasmani dan rohani. Tubuh berasal dari material (tanah) maka ia akan kembali kepada tanah setelah mati, sedang roh berasal dari inmaterial (Allah) maka ia juga akan kembali kepada Allah setelah manusia mati.

Dua unsur yang membentuk manusia tersebut, mempunyai kecenderungan untuk berkembang. Pada unsur jasmani, manusia cenderung berkembang dari kecil menjadi besar dan dari lemah menjadi kuat kemudian lemah lagi. Pada unsur rohani dari aspek berfikirnya, manusia ada yang berkembang dari "tidak tahu apaapa" menjadi tahu banyak hal, lalu kemudian mati, Ada pula yang berkembang dari tidak tahu kemudian menjadi tahu, lalu menjadi tidak tahu lagi karena ketuaan atau pikun lalu mati, firman Allah:

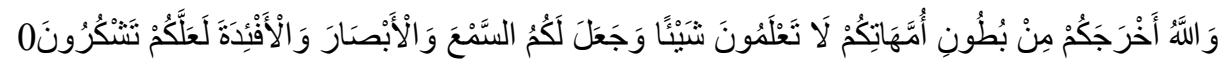

\footnotetext{
${ }^{20}$ M.Quraish Shihab, Membumikan Alquran, Op. Cit., h.172.

${ }^{21}$ Hery Noer Aly, Op. Cit., h. 67
} 
Dan Allah mengeluarkan kamu dari perut ibumu dalam keadaan tidak mengetahui sesuatupun, dan Dia memberi kamu pendengaran, peneglihatan dan hati agar kamu bersyukur. (Q.S. al-Nahl [16]: 78)

Perkembangan unsur-unsur jasmani dan rohani manusia, banyak dipengaruhi oleh faktor lingkunan, terutama karena berhubungan dengan pemenuhan kebutuhan, baik pemenuhan kebutuhan primer maupun kebutuhan sekunder. Namun manusia tidak dapat berkembang dengan sendirinya, perkembangannya banyak bergantung pada pengaruh lingkungan. Pendidikan merupakan lingkungan yang paling penting dalam membantu manusia untuk mencapai perkembangannya. Oleh sebab itu, dalam Islam, penyelenggaraan pendidikan merupakan suatu keharusan.

Oleh sebab itu pula dalam pendidikan Islam, dua unsur dalam diri manusia jasmani dan rohani yang membentuk manusia dengan segala potensinya samasama mendapatkan perhatian. Unsur jasmani tidak lebih penting dari unsur rohani, demikian pula sebaliknya karena kedua unsur tersebut saling mempengaruhi.

\section{B. Tujuan Pendidikan dan Tujuan Hidup Manusia.}

Tujuan pendidikan ialah orientasi yang dipilih oleh pendidik dalam membimbing peserta didiknya serta mengarahkan proses pendidikan. Tujuan pendidika berkaitan erat dengan nilai-nilai yang dijunjung tinggi dalam kehidupan pendidiknya, dengan perkataan lain tujuan pendidikan tidak bisa dipisahkan dari tujuan hidup pendidik.

Konsep-konsep dasar dalam pendidikan Islam merupakan suatu usaha yang berproses yang dilakukan oleh manusia secara sadar dalam membimbing manusia dalam menuju kepada kesempurnaannya berdasarkan ajaran Islam. Oleh sebab itu, dalam suatu proses pendidikan yang akan dilangsungkan maka akan memanculkan masalah-masalah yang sangat terkait dengan beberapa unsur, antara lain adalah; 1) tujuan yang ingin dicapai, 2) peserta didik, 3) pendidik, 4) isi atau bahan ajar, 5) metode yang digunakan, dan 6) ruang waktu.

Di samping itu, tujuan yang ingin dicapai dalam pendidikan, tidak dapat dipisahkan dengan tujuan manusia diciptakan oleh Allah yaitu:

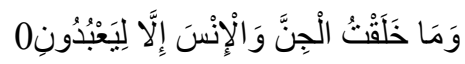

Dan Aku tidak menciptakan dan manusia, melainka supaya mereka menyembah$K u$. (Q.S. al-Dzariyat [51]: 56)

Atas dasar ini, dapat disimpulkan bahwa pendidikan yang diberikan oleh AlQuran adalah untuk membina manusia secara pribadi dan kelompok agar ia mampu menjalankan fungsinya sebagai hamba dan khalifah Allah yang akan membangun serta memakmurkan dunia sesuai dengan konsep yang telah ditetapkan oleh Allah:

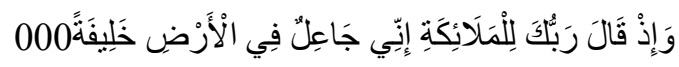

Ingatlah, ketika Tuhanmu berfiram kepada Malaikat; Sesungguhnya Aku akan menciptakan manusia sebagai khalifah di muka bumi...(Q.S. al-Baqarah [2]: 30)

Al-Quran sebagai ajaran yang datang dari Allah, kebenarannya bersifat mutlak dan kekal, oleh sebab itu sikap keagamaan orang mu'min terhadap AlQuran adalah memahami kebenaran pernyataan-pernyataannya dengan bertitik tolak dari keyakinan, bukan sesuatu yang dapat dibuktikan melalui dengan telaah 
yang berdasarkan teori, hipotesis, atau asumsi ilmiah yang membutuhkan pembuktian dengan bertitik tolak dari keraguan.

Al-Quran membahas berbagai aspek kehidupan manusia, dan salah satu aspek yang merupakan tema terpenting yang dibahasnya adalah pendidikan. Setiap ayat-ayatnya merupakan bahan baku bangunan pendidikan yang dibutuhkan setiap manusia, hal ini menunjukkan bahwa Al-Quran merupakan kitab hidayah, dan seseorang yang memperoleh hidayah tidak lain karena pendidikan yang benar serta ketaatannya. ${ }^{22}$

Sebagaimana telah disinggung terdahulu bahwa dalam proses prndidikan akan muncul masalah-masalah yang terkait antara lain menyangkut dengan tujuan, artinya dalam suatu proses pendidikan harus ditentukan adanya tujuan yang ingin dicapai. Tujuan ini memiliki orientasi yang dipilih oleh sipendidik dalam membimbing peserta didiknya.

Dengan demikian, pada dasarnya tujuan pendidikan merupakan kristalisasi nilai-nilai, yakni berupa daya pendorong dalam hidup yang dapat memberikan makna dan pengabsahan pola tingkah-laku seseorang. ${ }^{23}$

Tujuan akhir ialah tujuan yang hendak dicapai oleh pendidik terhadap peserta didiknya melalui seluruh rangkaian proses pendidikan, dimaksudkan dengan tujuan akhir karena dengan tercapainya tujuan ini maka berakhir pulalah seluruh rangkaian pendidikan.

Para ahli pendidikan Islam telah memberikan rumusan mengenai tujuan akhir pendidikan Islam dalam redaksi yang berbeda-beda, antara lain:

Tujuan akhir pendidikan Islam ialah kesempurnaan insani di dunia dan di akhirat. Manusia dapat mencapai kesempurnaan melalui pencarian keutamaan dengan menggunakan ilmu, keutamaan itu akan memberikan kebahagiaan di dunia serta mendekatkannya kepada Allah sehingga ia mendapatkan pula kebahagiaan di akhirat, (Al-Ghazali). ${ }^{24}$

Tujuan tertinggi pendidikan Islam adalah tercapainya akhlaq yang sempurna atau keutamaan, (Athiyah al-Abrasyi). ${ }^{25}$

Tujuan akhir pendidikan Islam adalah terbentuknya kepribadian Muslim, (Ahmad D. Marimba). ${ }^{26}$

Dari beberapa redaksi mengenai tujuan akhir Pendidikan Islam yang dikemukakan oleh para ahli, sesungguhnya tidaklah saling bertentangan antara satu dengan yang lainnya jika dilihat dari penafsiran dan penekanan terhadap redaksi yang dibawakannya, yakni semua mengarah kepada kesempurnaan kualitas sebagai manusia atau Insal Kamil. Di samping itu, tujuan hidup

${ }^{22}$ Ahmad Ibrahim Muhanna, Al-Tarbiyah fi al-Islam, (Kairo: Dar al-Sya'bi, 1982), h. 13.

${ }^{23}$ Hery Noer Aly, Op., Cit., h. 55

${ }^{24}$ Fathiyah Hasan Sulaiman, Madzahib fi al-Tarbiyah: Bahtsun fi al-Madzhab al-Tarbawy 'Inda al-Ghazali, Terj. Oleh: Hery Noer Ali, (Bandung: Diponegoro, 1986), h. 18.

${ }^{25}$ Muhammad Athiyah al-Abrasyi, Al-Tarbiyah al-Islamiyah, (Mesir: Dar al-Fikr, t.th), h. $22-23$.

${ }^{26}$ Ahmad D. Marimba, Filsafat Pendidikan Islam, (Bandung: Al-Ma'arif, 1980), h. 46 
merupakan pula sumber tujuan pendidikan Islam, artinya tujuan akhir pendidikan Islam pada intinya merupakan penjabaran dari tujuan hidup manusia.

Jika dalam pendidikan terlihat adanya perbedaan tujuan yang hendak dicapai dalam suatu proses pendidikan, hal itu disebabkan oleh perbedaan tujuan hidup pendidik. Sementara itu, perbedaan tujuan hidup di kalangan manusia sebagai pandidik, adalah disebabkan oleh karena perbedaan pandangan hidup yang menyangkut dengan hakekat manusia dan kedudukannya di alam semesta serta akhir hidupnya masing-masing.

Dari uraian tentang hakekat manusia menurut Al-Quran dalam hubungannya dengan pendidikan dapat diketahui bahwa tujuan hidup manusia adalah memperoleh keridhaan Allah swt., yakni manusia yang menjalankan peranan idealnya sebagai hamba dalam arti mengabdi kepada Allah, serta menjalankan peranan idealnya sebagai khalifah Allah dalam arti yang akan memakmurkan bumi secara sempurna.

Manusia dimaksud adalah manusia yang memiliki ciri-ciri mengenali, meyakini dan melaksanakan secara sempurna peranan idealnya dalam sistem penciptaannya sebagai manusia. Hanya masalahnya, bagaima mengukur tujuan akhir pendidikan Islam seperti yang telah dipaparkan di atas, dalam arti bagaimana menentukan siapakah manusia yang telah mencapai kesempurnaan itu, sesungguhnya penentuan mengenai hal itu bukanlah wewenang manusia melainkan Tuhan-lah yang akan menentukan siapa-siapa di antara hamba-Nya yang telah mencapai kesempurnaan itu. Dan disinilah letak rahasianya mengapa pendidikan Islam itu berlangsung sepanjang hayat (long life education), artinya manusia harus senantiasa berusaha secara terus-menerus untuk mencapai kesempurnaan itu.

\section{Penutup}

Manusia menurut pandangan Al-Quran adalah makhluq yang diciptakan terdiri dari dua unsur yakni; unsur jasmani dan unsur rohani. Sekaligus makhluq yang diciptakan dan paling mulia di antara makhluq-makhluq ciptaan Allah, yang memiliki potensi-potensi yang dapat dikembangkan melalui dengan pendidikan.

Manusia sebagai makhluq yang memiliki kecenderungan-kecenderungan untuk berkembang, maka melalui pendidikan ia harus senantiasa berusaha secara terus-menerus untuk mencapai kesempurnaannya, untuk dapat menjalankan peranan idealnya sebagai Insan Kamil agar fungsinya sebagai manusia dapat pula terlaksana yakni sebagai hamba dan khalifah Allah yang diutus untuk dapat memakmurkan dunia. 


\section{DAFTAR PUSTAKA}

Aly, Hery Noer, Ilmu Pendidikan Islam, Cet. II, (Jakarta : Logos Wacara Ilmu, 1999

al-Abrasyi, Muhammad Athiyah, Al-Tarbiyah al-Islamiyah, Mesir: Dar al-Fikr, t.th

al-Fayuny, Ahmad Ibnu Muhammad, Al-Mishbah al-Munir fi Gharib al-Syarh alKabir li al-Rafi'i, Kairo: Dar al-Fikr, t.th.

Ibnu Manzur, Ibnu Mukarram, Lisan al-'Arabi, Jilid VI, Mesir: Dar al-Shadr, 1969

Langgulung, Hasan, Azas-Azas Pendidikan Islam, Edisi Revisi, Cet. I, (Jakarta: PT. Al-Husna Dzikra, 2000

Marimba, Ahmad D., Filsafat Pendidikan Islam, Bandung: Al-Ma'arif, 1980

Mastuhu, M.Ed., Memberdayakan Sistim Pendidikan Islam, Cet. II, Jakarta: Logos Wacana Ilmu, 1999

Muhammad, Ahmad Ibrahim, Al-Tarbiyah fi al-Islam, (Kairo: Dar al-Sya'bi, 1982.

Nasution, Harun, Konsep Manusia Menurut Islam, Dalam Saiful Muzani, ed., Islam Rasional, Gagasan dan Pemikiran Prof Dr. Harun Nasution, Cet. VI, Bandung: Mizan, 2000

al-Raghib, Abu al-Qasim bin Muhammad al-Ashfahani, Mufradat fi Gharib AlQuran, Mesir: Mushthafa Bab al-Halabi, 1961

Shihab, M. Quraish, Membumikan Alquran, Fungsi dan Peran Wahyu dalam Kehidupan bermasyarakat, Cet. XX, Bandung: Mizan, 1999

--------, Wawasan Alquran, Tafsir Maudhu'i Atas Pelbagai Persoalan Ummat, Cet. VII, Bandung: Mzan, 1998

Sulaiman, Fathiyah Hasan, Madzahib fi al-Tarbiyah: Bahtsun fi al-Madzhab alTarbawy 'Inda al-Ghazali, Terj. Oleh: Hery Noer Ali, (Bandung: Diponegoro, 1986 